\title{
The Sea Ice Fauna of Frobisher Bay, Arctic Canada
}

\author{
E.H. GRAINGER,' A.A. MOHAMMED,' and J.E. LOVRITY'1
}

\begin{abstract}
The fauna of the lower few centimetres of the sea ice in Frobisher Bay, Arctic Canada, consists mainly of meroplanktonic young of benthic adults and holoplanktonic representatives of generally benthic groups. The major arctic zooplankton species are not included. The ice fauna comprises nematodes, harpacticoid copepods, polychaete larvae, ciliates, various benthic larvae, young gammaridean amphipods, and others. Some species occur in the ice as young animals only, others in all stages of development. Adaptation to the ice is shown best by the copepods, some of which occur there in all stages from egg to adult. The most abundant ice inhabitants reach high concentrations in the ice (nematodes more than 100000 , Cyclopina nearly $10000 \cdot \mathrm{m}^{-2}$ ). Others appear to show only accidental presence in the ice, and are found in small numbers only, often at times when great numbers of the same species are present in the water below the ice. Probable feeding of the ice fauna and the food chain linking the ice flora to vertebrate predators are discussed.
\end{abstract}

Key words: arctic waters, sea ice, ice fauna, food chain, zooplankton

RÉSUMÉ. La faune présente dans les quelques centimètres inférieurs de la glace marine de la baie de Frobisher, est constituée principalement de juvéniles méroplanctoniques dont les formes adultes appartiennent au benthos et de représentants holoplanctoniques de groupes généralement benthiques. Nous n'y retrouvons point les principales espèces du zooplancton arctique. La faune de la glace comprend des nématodes, des copépodes harpacticoides, des larves de polychètes, des ciliés, différentes larves benthiques, des amphipodes gammarides juvéniles et bien d'autres. Certaines espèces ne se retrouvent dans la glace qu'à l'état juvénile, tandis que d'autres sont représentées par des animaux ayant atteint des stades variés de développement. Les copépodes représentent le groupe s'étant le mieux adapté à la vie dans la glace; certains d'entre eux s'y retrouvent à tous les stades de leur développement, de l'oeuf jusqu'à la forme adulte. Les habitants de la glace les plus abondants y atteignent des concentrations élevées (les nématodes plus de 100000 , Cyclopina près de $10000 \cdot \mathrm{m}^{-2}$ ). D'autres semblent $n$ 'apparaître dans la glace qu'accidentellement et en nombre réduit, souvent lorsqu'un grand nombre d'individus de la même espèce évoluent dans les eaux sous-jacentes. Le mode du nutrition probable de la faune de la glace de même que les liens unissant celle-ci aux prédateurs vertébrés au travers de la châne alimentaire sont discutés.

Mots clés: eaux de l'arctique, glace marine, faune de la glace, chaîne alimentaire, zooplancton

Traduit par C. Bédard, T. Cartier, F. Dugré et J. Laliberté.

\section{INTRODUCTION}

Considerable interest in plants found in sea ice, both arctic and antarctic, was shown throughout the second half of the nineteenth century, but it was not until Nansen (1906) observed ciliates on the surface of ice in the Arctic Ocean that animals were also recognized as sea ice inhabitants. Nansen concluded that the protozoans were of marine origin, frozen into the ice in autumn.

In his 1906 work, Nansen referred to an earlier observation of his made in 1882 in East Greenland waters. There he had noticed that ice $30-60 \mathrm{~cm}$ thick was frequently coloured reddish-brown on the underside. It was called "seal-ice" by the sealers because the seals seemed to prefer it. Nansen recognized the coloured material as diatoms, and suggested the existence of a trophic link between the under-ice diatoms, crustaceans which he stated would be expected to be attracted by the diatoms, and seals, which would feed on the crustaceans. This may have been the first serious statement on the ice-based food chain which, almost exactly 100 years later, we are still far from understanding clearly.

Nearly half a century passed before Usachev's (1949) account of protozoans in ice in the Kara Sea appeared. He found several ciliates, including Euplotes candata Meunier, E. truncata Meunier, Proboscidium armatum Meunier, Cephalotrichium tonsuratum Meunier, Amphorella vitrea (Brandt) and Difflugia sp.

This was followed by a series of reports on the larger and more readily visible amphipods found associated with the lower surface of the ice. MacGinitie (1955) observed large numbers of Apherusa glacialis on the underside of ice floes on the north coast of Alaska. Barnard (1959) reported Gammaracanthus loricatus as possibly associated with the sea ice and Onisimus (as Pseudalibrotus) nanseni and Gammarus wilkitzkii as positively associated with the ice of the central Arctic Ocean. Horner (1972) found Onisimus (as Pseudalibrotus) litoralis, Gammaracanthus loricatus, and Gammarus wilkitzkii on the lower surface of the ice on the north Alaska coast.

Amphipods (Apherusa glacialis and Gammarus setosus) of the "cryopelagic biocoenosis" in the Soviet Arctic were discussed by Golikov and Scarlato (1973). Green and Steele (1975) observed Gammarus setosus and Gammaracanthus loricatus on the lower surface of the ice in Resolute Bay, and Welch and Kalff (1975) described unidentified amphipods from the same bay.

Some highly detailed information was supplied by Buchanan et al. (1977) on under-ice amphipods from Bridport Inlet, Melville Island. Three species of Onisimus $(O$. litoralis, $O$. glacialis, and $O$. nanseni) along with Gammarus setosus and Gammaracanthus loricatus were discussed in relation to the ice surface. Mention was made also of the amphipods Gammarus wilkitzkii and Apherusa glacialis.

Several amphipods and copepods and a single mysid were shown in loose association with the lower surface of the ice of the Arctic Ocean by Mel'nikov and Kulikov (1980). Several of

'Arctic Biological Station, 555 St. Pierre Boulevard, Ste. Anne de Bellevue, Quebec, Canada H9X 3R4 
the species above, with the addition of Apherusa megalops and Weyprechtia pinguis, were found just under the February ice on the north Alaskan coast by Griffiths and Dillinger (1981). A number of familiar amphipods along with previously unreported Ischyrocerus anguipes, Eusirus holmi, and Parathemisto libellula and the mysid Mysis polaris were listed by Cross (1982a) from beneath the ice in Pond Inlet, north Baffin Island. Many of the same amphipods, with the addition of Pontogeneia inermis, were taken at Cape Hatt, north Baffin Island, by Cross (1982b).

Horner and Alexander (1972) seem to be the first to have looked for the smaller multi-cellular animals within arctic sea ice (Andriashev (1968) had already done so in the Antarctic, and had shown the presence of young polychaetes, calanoid, cyclopoid, and harpacticoid copepods and amphipods). They produced from the north Alaskan coast the most interesting and diversified list of ice animals to date, including ciliates, mainly hypotrichs of the genera Euplotes and Stylonchia, unidentified heliozoans, nematodes, polychaetes, turbellarians, and a single small, unnamed copepod. More recently, Cross (1982a) reported a number of invertebrate animals from the bottom layer of ice in Pond Inlet, north Baffin Island, and Carey and Montagna (1982) and Kern and Carey (1983) described an invertebrate ice fauna from north Alaska. These included such small ice-dwelling animals as nematodes, rotifers, polychaete larvae, and crustaceans.

Considerable knowledge of the ice flora has already been assembled (Horner, 1977; Hsiao, 1980), and indications given of the potential importance of the ice plants as a food source for plankton and fishes. Fairly extensive information has been gathered on the larger animals associated mainly with the bottom of the ice. Knowledge of the smaller animals living within the ice has remained rudimentary, however, regarding their identity and number, their possible mobility and relationships with the fauna in the water beneath the ice, their food and predators, their origin, and their fate when the ice melts in spring.

Our study was carried out in Frobisher Bay, in the eastern Canadian Arctic, at a nearshore site $\left(63^{\circ} 42.8^{\prime} \mathrm{N}, 68^{\circ} 30.8^{\prime} \mathrm{W}\right)$ between 40 and $50 \mathrm{~m}$ deep (Fig. 1). Physical and chemical properties of the ice and water below were measured at the times of ice sampling (Grainger and Hsiao, 1982; Lovrity, 1982; and unpublished data of the Arctic Biological Station). Collections considered here were made during the winterspring periods of 1981 and 1982.

\section{METHODS}

Ice fauna was collected in two ways. The first method involved digging holes $60-90 \mathrm{~cm}$ in diameter, going from the surface down to about $15 \mathrm{~cm}$ from the bottom of the ice. The remaining ice was carefully extracted from the holes and retrieved with as little disturbance to the lower surface as possible. Alternatively, we used a SIPRE ice corer, which delivers a core $7.2 \mathrm{~cm}$ in diameter. Generally only single samples were taken. Visual (diver) examination from below of the penetration of the lower surface from above and the lifting

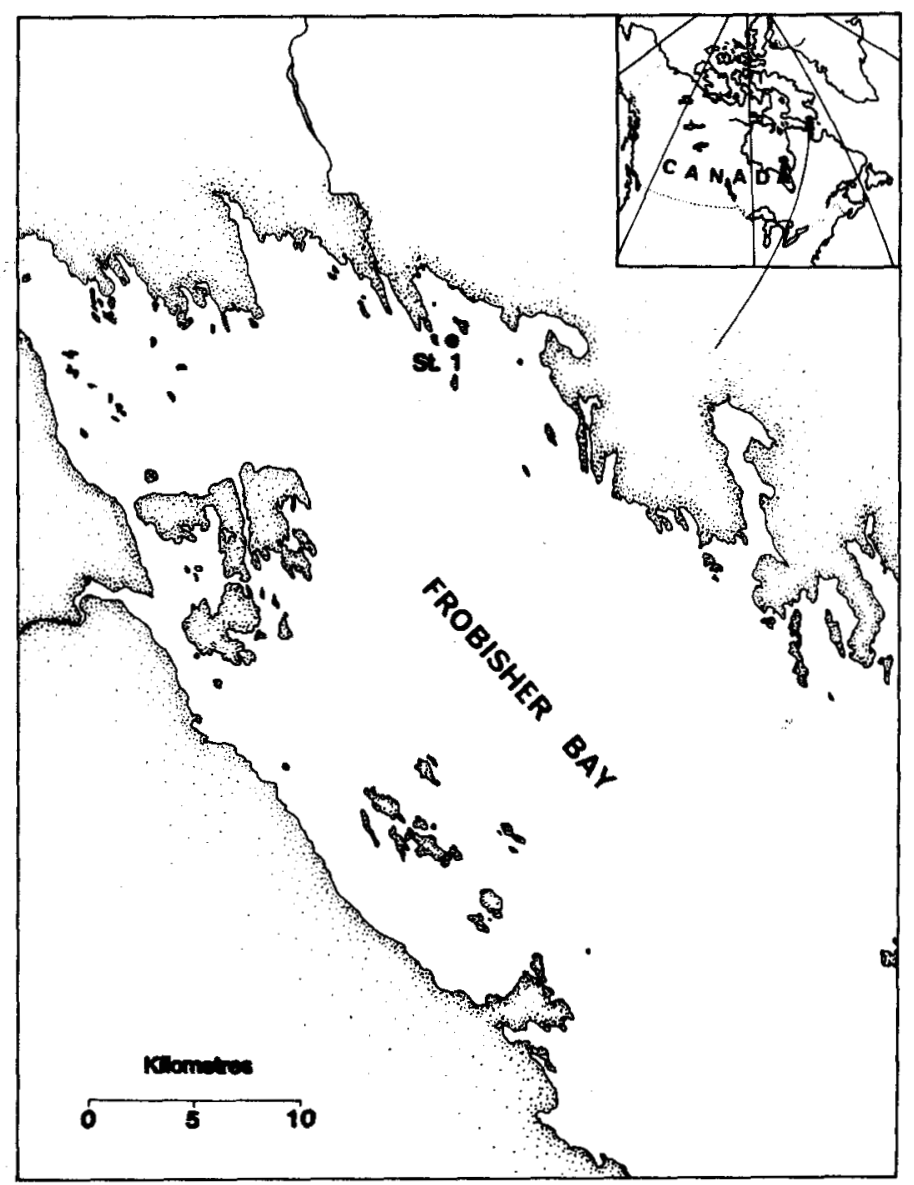

FIG. 1. Origin of sea ice collections (St. 1) in upper Frobisher Bay, Baffin Island.

of ice in both procedures showed little loss of material from within the lower surface of the ice.

Following collection, the ice samples were melted and excess water drained through nylon mesh ( $73 \mu \mathrm{m}$ for the first collection of 1981 , then $10 \mu \mathrm{m}$ for the remaining samples of both years). All organisms retained were identified and counted. The change to a finer mesh was made to reduce possible loss of the smaller organisms such as nematodes and ciliates. Such loss through the larger mesh appeared in fact to be extremely small.

For comparison with ice samples, zooplankton was collected from the water beneath the ice, using $73-\mu \mathrm{m}$ mesh nets hauled vertically. Additionally, water was pumped from a few centimetres below the ice, and the zooplankton taken was retained on a $73-\mu \mathrm{m}$ mesh. We also used a hand-operated icebottom sampler.

\section{RESULTS}

The sea ice sampled ranged in thickness from 80 to $159 \mathrm{~cm}$ during the collection periods, the snow cover from negligible to about $50 \mathrm{~cm}$. Salinity was variable in the water immediately under the ice (7.5-33.6\%), and water temperature was consistently low $\left(-1.8\right.$ to $\left.-0.1^{\circ} \mathrm{C}\right)$.

The Frobisher Bay sea-ice fauna collected in 1981 and 1982 
is listed in Tables 1 and 2 . Table 1 includes numbers of the iceinhabiting species collected in the plankton under the ice. Nematodes were the most numerous individuals in the ice (up to more than 100000 in the lower $3 \mathrm{~cm}$ of ice under $1 \mathrm{~m}^{2}$ ), and they were consistently more abundant in the ice than in the water samples. Mollusc larvae were consistently less numerous in the ice than in the water samples, peaking in May in the ice but continuing through the spring to increase in numbers in the water. Numbers of Cyclopina declined progressively in the ice collections from the first to the last sampling date. Numbers in the water samples were low initially, then grew rapidly in June. Tisbe in the water, outnumbering those collected in the ice for most of the period, declined until May, then increased slightly while numbers fell in the ice. Copepod

TABLE 1. Sea ice fauna, Frobisher Bay, 1981. Numbers $\cdot \mathrm{m}^{-2}$ (in the lower $3 \mathrm{~cm}$ of ice and in $40-50 \mathrm{~m}$ of water)

\begin{tabular}{|c|c|c|c|c|c|c|c|c|c|c|}
\hline \multirow[t]{2}{*}{ Ice thickness (cm) } & \multicolumn{2}{|c|}{$\begin{array}{c}14 \text { Feb } 81 \\
123\end{array}$} & \multicolumn{2}{|c|}{$\begin{array}{c}24 \operatorname{Mar} 81 \\
142\end{array}$} & \multicolumn{2}{|c|}{$\begin{array}{c}1 \text { May } 81 \\
145\end{array}$} & \multicolumn{2}{|c|}{$\begin{array}{c}27 \text { May } 81 \\
148\end{array}$} & \multicolumn{2}{|c|}{$\begin{array}{c}19 \text { Jun } 81 \\
137\end{array}$} \\
\hline & Ice & Water & lce & Water & Ice & Water & Ice & Water & Ice & Water \\
\hline $\begin{array}{l}\text { Ciliates } \\
\text { Other protozoans }\end{array}$ & $\begin{array}{r}0 \\
520\end{array}$ & $\begin{array}{l}\mathbf{0} \\
\mathbf{0}\end{array}$ & $\begin{array}{l}\mathbf{0} \\
\mathbf{0}\end{array}$ & $\begin{array}{r}713 \\
0\end{array}$ & $\begin{array}{r}720 \\
0\end{array}$ & $\begin{array}{r}158 \\
0\end{array}$ & $\begin{array}{r}14 \\
0\end{array}$ & $\begin{array}{r}0 \\
42\end{array}$ & $\begin{array}{r}40 \\
0\end{array}$ & $\begin{array}{l}0 \\
0\end{array}$ \\
\hline Nematodes & 10560 & 185 & 30320 & 57 & 20700 & 70 & 108800 & 168 & 16000 & 1080 \\
\hline Polychaete larvae & 460 & 1927 & 110 & 2542 & 8040 & 1584 & 28 & 504 & $\mathbf{0}$ & 16800 \\
\hline Rotifers & 40 & $\mathbf{0}$ & 240 & $\mathbf{0}$ & 400 & 114 & 14 & 13 & 460 & 320 \\
\hline $\begin{array}{l}\text { Pelecypod larvae } \\
\text { Gastropod larvae }\end{array}$ & $\begin{array}{l}\mathbf{0} \\
\mathbf{0}\end{array}$ & $\begin{array}{r}0 \\
115\end{array}$ & $\begin{array}{l}\mathbf{0} \\
\mathbf{0}\end{array}$ & $\begin{array}{r}0 \\
1148\end{array}$ & $\begin{array}{r}1680 \\
0\end{array}$ & $\begin{array}{r}6248 \\
339\end{array}$ & $\begin{array}{r}400 \\
14\end{array}$ & $\begin{array}{r}12726 \\
0\end{array}$ & $\begin{array}{r}20 \\
0\end{array}$ & $\begin{array}{r}39760 \\
1160\end{array}$ \\
\hline Balanus larvae & $\mathbf{0}$ & 0 & $\mathbf{0}$ & 0 & $\mathbf{0}$ & 154 & 0 & 421 & 20 & 19440 \\
\hline $\begin{array}{l}\text { Acartia longiremis (Lilljeborg) } \\
\text { Cyclopina sp. } \\
\text { VIM } \\
\text { VIF } \\
\text { V } \\
\text { IV } \\
\text { III } \\
\text { II } \\
\text { I }\end{array}$ & $\begin{array}{r}5 \\
2175 \\
5 \\
15 \\
5 \\
5 \\
70 \\
1790 \\
285\end{array}$ & $\begin{array}{r}4633 \\
0 \\
0 \\
0 \\
0 \\
0 \\
0 \\
0 \\
0\end{array}$ & $\begin{array}{r}0 \\
1770 \\
0 \\
40 \\
0 \\
10 \\
150 \\
720 \\
850\end{array}$ & $\begin{array}{r}4633 \\
114 \\
0 \\
57 \\
0 \\
0 \\
57 \\
0 \\
0\end{array}$ & $\begin{array}{r}\text { IBS* } \\
800 \\
0 \\
680 \\
0 \\
0 \\
120 \\
0 \\
0\end{array}$ & $\begin{array}{r}4444 \\
114 \\
0 \\
0 \\
0 \\
0 \\
114 \\
0 \\
0\end{array}$ & $\begin{array}{l}\text { IBS* } \\
98 \\
0 \\
28 \\
14 \\
14 \\
28 \\
14 \\
0\end{array}$ & $\begin{array}{r}840 \\
39 \\
0 \\
0 \\
13 \\
0 \\
13 \\
0 \\
13\end{array}$ & $\begin{array}{l}\mathbf{0} \\
\mathbf{0} \\
\mathbf{0} \\
\mathbf{0} \\
\mathbf{0} \\
\mathbf{0} \\
\mathbf{0} \\
\mathbf{0} \\
\mathbf{0}\end{array}$ & $\begin{array}{r}0 \\
332 \\
32 \\
16 \\
72 \\
28 \\
84 \\
100 \\
0\end{array}$ \\
\hline $\begin{array}{l}\text { Ectinosoma sp. } \\
\text { Harpacticus superflexus Willey } \\
\text { VIM } \\
\text { VIF } \\
\text { V } \\
\text { IV } \\
\text { III } \\
\text { II } \\
\text { I }\end{array}$ & $\begin{array}{r}0 \\
20 \\
0 \\
20 \\
0 \\
0 \\
0 \\
0 \\
0\end{array}$ & $\begin{array}{r}29 \\
12 \\
0 \\
12 \\
0 \\
0 \\
0 \\
0 \\
0\end{array}$ & $\begin{array}{r}10 \\
50 \\
0 \\
10 \\
0 \\
0 \\
0 \\
40 \\
0\end{array}$ & $\begin{array}{l}0 \\
0 \\
0 \\
0 \\
0 \\
0 \\
0 \\
0 \\
0\end{array}$ & $\begin{array}{c}0 \\
\text { IBS* } \\
0 \\
0 \\
0 \\
0 \\
0 \\
0 \\
0\end{array}$ & $\begin{array}{r}13 \\
0 \\
0 \\
0 \\
0 \\
0 \\
0 \\
0 \\
0\end{array}$ & $\begin{array}{r}0 \\
84 \\
14 \\
14 \\
42 \\
0 \\
0 \\
14 \\
0\end{array}$ & $\begin{array}{r}0 \\
13 \\
0 \\
13 \\
0 \\
0 \\
0 \\
0 \\
0\end{array}$ & $\begin{array}{r}0 \\
20 \\
0 \\
0 \\
0 \\
0 \\
0 \\
0 \\
20\end{array}$ & $\begin{array}{r}76 \\
76 \\
16 \\
44 \\
16 \\
0 \\
0 \\
0 \\
0\end{array}$ \\
\hline 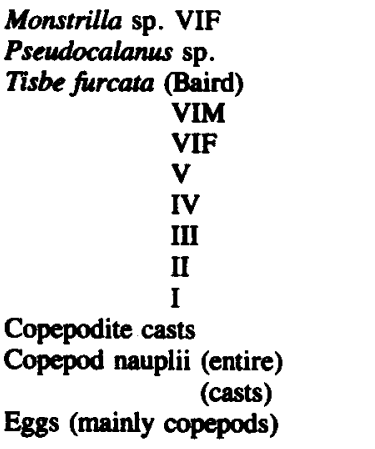 & $\begin{array}{r}5 \\
0 \\
255 \\
100 \\
70 \\
25 \\
20 \\
10 \\
30 \\
0 \\
120^{1} \\
90920 \\
2440 \\
7040\end{array}$ & $\begin{array}{r}0 \\
54530 \\
2108 \\
312 \\
312 \\
451 \\
451 \\
283 \\
242 \\
57 \\
1851 \\
697 \\
0 \\
4305\end{array}$ & $\begin{array}{c}0 \\
\text { IBS* } \\
310 \\
80 \\
50 \\
70 \\
80 \\
30 \\
0 \\
0 \\
70^{1} \\
26080 \\
0 \\
2720\end{array}$ & $\begin{array}{r}0 \\
43091 \\
1746 \\
0 \\
57 \\
1066 \\
451 \\
115 \\
57 \\
0 \\
2831 \\
1025 \\
57 \\
1886\end{array}$ & $\begin{array}{r}0 \\
0 \\
120 \\
0 \\
0 \\
0 \\
0 \\
0 \\
120 \\
0 \\
380^{1} \\
4200 \\
0 \\
7880\end{array}$ & $\begin{array}{r}0 \\
24200 \\
537 \\
128 \\
57 \\
313 \\
0 \\
26 \\
13 \\
0 \\
2992 \\
1936 \\
229 \\
792\end{array}$ & $\begin{array}{c}0 \\
\text { IBS* } \\
70 \\
14 \\
0 \\
56 \\
0 \\
0 \\
0 \\
0 \\
2002^{2} \\
800 \\
98 \\
0\end{array}$ & $\begin{array}{r}0 \\
6846 \\
68 \\
42 \\
0 \\
13 \\
0 \\
0 \\
13 \\
0 \\
391 \\
1302 \\
0 \\
3696\end{array}$ & $\begin{array}{r}0 \\
0 \\
0 \\
0 \\
0 \\
0 \\
0 \\
0 \\
0 \\
0 \\
20^{3} \\
800 \\
1600 \\
60\end{array}$ & $\begin{array}{r}0 \\
17360 \\
260 \\
72 \\
144 \\
16 \\
0 \\
0 \\
28 \\
0 \\
232^{4} \\
8440 \\
0 \\
15080\end{array}$ \\
\hline Onisimus sp. & 60 & $\mathbf{0}$ & 110 & 0 & 120 & 0 & IBS* & 0 & 0 & $\mathbf{0}$ \\
\hline Tunicate larvae & 0 & 451 & 40 & $\mathbf{0}$ & $\mathbf{0}$ & 0 & 14 & 25 & $\mathbf{0}$ & $\mathbf{0}$ \\
\hline
\end{tabular}

*IBS = ice bottom sampler collections, non-quantitative

'Mainly Tisbe

${ }^{2} H$. superflexus (1862), Tisbe (98), Cyclopina sp. (42)

${ }^{3}$ All $H$. superflexus

"Mainly Harpacticus 
TABLE 2. Sea ice fauna, Frobisher Bay, 1982. Numbers $\cdot \mathrm{m}^{-2}$ (in the lower $3 \mathrm{~cm}$ )

\begin{tabular}{|c|c|c|c|}
\hline Ice thickness (cm) & $\begin{array}{c}3 \text { Feb } 82 \\
80 \\
\end{array}$ & $\begin{array}{c}24 \underset{\operatorname{Mar} 82}{141} \\
\end{array}$ & $\begin{array}{c}13 \text { May } 82 \\
159 \\
\end{array}$ \\
\hline $\begin{array}{l}\text { Ciliates } \\
\text { Other protozoans }\end{array}$ & $\begin{array}{r}585 \\
68\end{array}$ & $\begin{array}{r}9 \\
28\end{array}$ & $\begin{array}{r}164 \\
0\end{array}$ \\
\hline Nematodes & 8282 & 1962 & 14606 \\
\hline Polychaete larvae & $\mathbf{0}$ & 3460 & 82 \\
\hline Rotifers & 68 & 1637 & 2694 \\
\hline Gastropod larvae & $\mathbf{0}$ & 9 & 0 \\
\hline $\begin{array}{c}\text { Cyclopina sp. } \\
\text { VIM } \\
\text { VIF } \\
\text { V } \\
\text { IV } \\
\text { III } \\
\text { II } \\
\text { I }\end{array}$ & $\begin{array}{r}3680 \\
15 \\
66 \\
15 \\
9 \\
0 \\
1460 \\
2115\end{array}$ & $\begin{array}{r}9364 \\
0 \\
130 \\
0 \\
28 \\
446 \\
3422 \\
5338\end{array}$ & $\begin{array}{r}82 \\
0 \\
18 \\
0 \\
0 \\
0 \\
0 \\
64\end{array}$ \\
\hline $\begin{array}{l}\text { Ectinosoma sp. } \\
\text { Harpacticus superflexus Willey } \\
\text { VIF } \\
\text { V } \\
\text { II } \\
\text { I }\end{array}$ & $\begin{array}{l}2 \\
3 \\
3 \\
0 \\
0 \\
0\end{array}$ & $\begin{array}{r}660 \\
381 \\
0 \\
0 \\
9 \\
372\end{array}$ & $\begin{array}{r}9 \\
18 \\
9 \\
9 \\
0 \\
0\end{array}$ \\
\hline $\begin{array}{l}\text { Monstrilla sp. } \\
\text { Pseudocalanus sp. } \\
\text { Tisbe furcata (Baird) } \\
\text { VIM } \\
\text { VIF } \\
\text { V } \\
\text { IV } \\
\text { III } \\
\text { II } \\
\begin{array}{ll} & \\
\text { Copepodite casts } \\
\text { Copepod nauplii }\end{array}\end{array}$ & $\begin{array}{r}9 \\
2 \\
31 \\
15 \\
7 \\
2 \\
7 \\
0 \\
0 \\
34 \\
48156\end{array}$ & $\begin{array}{r}0 \\
0 \\
1182 \\
140 \\
270 \\
223 \\
316 \\
177 \\
56 \\
205 \\
7886\end{array}$ & $\begin{array}{r}0 \\
0 \\
0 \\
0 \\
0 \\
0 \\
0 \\
0 \\
0 \\
130 \\
8891\end{array}$ \\
\hline Eggs (mainly copepod) & 3305 & 6919 & 410 \\
\hline Onisimus sp. & 19 & 140 & 9 \\
\hline Acarina (mites) & 0 & 0 & 18 \\
\hline Tunicate larvae & 46 & 9 & 0 \\
\hline
\end{tabular}

nauplii (all species combined) were especially numerous in the ice samples in February, after which time they declined through the rest of the season while numbers generally rose in the water collections.

Differences, some fairly large, are apparent between the two years sampled. Nematodes were more numerous in the collections from March and May of 1981 than in 1982, and mollusc larvae were also more abundant in the 1981 material. Rotifers and young stages of Cyclopina were more numerous in the ice samples in 1982 than in 1981. Total numbers taken in 1981 were roughly double those caught in 1982 .

Wet weights of major species and groups in the ice fauna are given in Table 3 for the 1981 collections, and comparisons of wet weights and counts for three of the collections in 1981 are shown in Figure 2. In February, numbers were accounted for mainly by copepod nauplii and nematodes, and weights by the copepod nauplii and individually large but relatively few Onisimus and polychaete larvae. Nematodes, polychaetes, and eggs were the most numerous in early May, at a time when polychaetes dominated the biomass and, along with Onisimus,
TABLE 3. Sea ice fauna, Frobisher Bay, Station $1,1981 . \mathbf{M g} \cdot \mathrm{m}^{-2}$ (wet) in the lower $3 \mathrm{~cm}$

\begin{tabular}{|c|c|c|c|c|c|}
\hline & 14 Feb & $24 \mathrm{Mar}$ & 1 May & $27 \mathrm{Ma}$ & 19 Jun \\
\hline Protozoans & 0 & $\mathbf{0}$ & 0.1 & + & + \\
\hline Nematodes & 10.6 & 30.3 & 20.7 & 108.8 & 16.0 \\
\hline Polychaete larvae & 36.8 & 8.8 & 643.2 & 2.2 & $\mathbf{0}$ \\
\hline Rotifers & + & 0.2 & 0.4 & + & 0.5 \\
\hline Mollusc larvae & $\mathbf{0}$ & 0 & 8.4 & 2.8 & 0.1 \\
\hline Balanus larvae & 0 & $\mathbf{0}$ & 0 & 0 & 0.4 \\
\hline Acartia longiremis (Lilljeborg) & 0.3 & 0 & $\mathbf{0}$ & $\mathbf{0}$ & 0 \\
\hline Cyclopina sp. & 9.0 & 7.3 & 15.0 & 1.2 & $\mathbf{0}$ \\
\hline Ectinosoma sp. & 0 & 0.3 & 0 & 0 & $\mathbf{0}$ \\
\hline Harpacticus superflexus Willey & 1.1 & 0.9 & 0 & 2.9 & 0.1 \\
\hline Monstrilla sp. & + & $\mathbf{0}$ & 0 & 0 & 0 \\
\hline Pseudocalanus sp. & $\mathbf{0}$ & $\mathbf{0}$ & 0 & $\mathbf{0}$ & $\mathbf{0}$ \\
\hline Tisbe furcata (Baird) & 8.8 & 7.6 & 0.5 & 2.0 & $\mathbf{0}$ \\
\hline Copepod nauplii & 454.6 & 130.4 & 21.0 & 4.0 & 4.0 \\
\hline Eggs & 7.0 & 2.7 & 7.9 & + & + \\
\hline Onisimus sp. & 120.0 & 220.0 & 240.0 & $\mathbf{0}$ & $\mathbf{0}$ \\
\hline \multirow[t]{2}{*}{ Tunicate larvae } & 0 & 2.0 & 0 & 0.7 & 0 \\
\hline & 648.2 & 410.5 & 957.2 & $\overline{124.6}$ & 21.2 \\
\hline
\end{tabular}

$+=$ fewer than $0.1 \mathrm{mg} \cdot \mathrm{m}^{-2}$

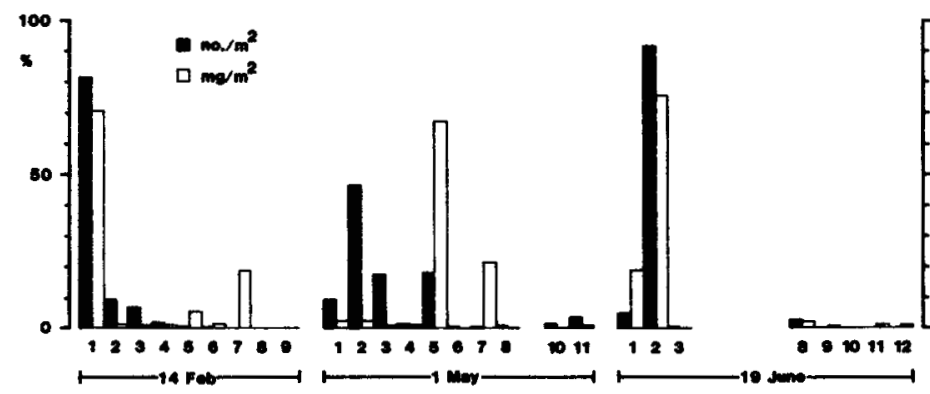

FIG. 2. Seasonal changes in number and wet weight of the sea ice fauna of Frobisher Bay in 1981. 1, copepod nauplii; 2, nematodes; 3, eggs; 4, Cyclopina; 5, polychaetes; 6, Tisbe; 7, Onisimus; 8, rotifers; 9, Harpacticus; 10 , ciliates; 11 , mollusc larvae; 12 , cirriped larvae.

accounted for most of the biomass measured. In June, nematodes were strongly dominant, both numerically and in biomass, followed in both categories by copepod nauplii.

An indication of comparative population levels of ice inhabitants in the ice and in the water below the ice was shown in Table 1. Table 4 examines the relationship from the point of view of major species in the plankton. The most abundant member of the zooplankton in February, March, and early May was Pseudocalanus sp., predominantly as stages C-III to C-V. Pseudocalanus and the second most plentiful planktonic copepod, Acartia longiremis, were both found very rarely in the ice. The two most abundant cyclopoid copepods in plankton, Oncaea borealis and Oithona similis, were not found at all in the Frobisher ice in 1981 or 1982 . Some groups were abundant in both locations, including copepod nauplii, eggs, and various benthic larvae. The most frequently occurring underice harpacticoid copepod, Tisbe furcata, was also the most numerous in the ice. Some were noticeably more numerous in the ice than in the water, including nematodes, rotifers, Cyclopina sp., Harpacticus superflexus, and young of the 
TABLE 4. Major planktonic forms taken in the water under the ice in Frobisher Bay, 1981

\begin{tabular}{|c|c|}
\hline Species & Species \\
\hline $\begin{array}{l}\text { Pseudocalanus sp. (*) } \\
\text { Acartia longiremis (Lilljeborg) (*) } \\
\text { Copepod eggs* } \\
\text { Tisbe furcata (Baird)* } \\
\text { Polychaete larvae* } \\
\text { Oncaea borealis G.o. Sars } \\
\text { Copepod nauplii* } \\
\text { Oithona similis Claus } \\
\text { Tunicate larvae* } \\
\text { Nematodes* } \\
\text { Metridia longa (Lubbock) } \\
\text { Gastropod larvae* } \\
\text { Oncaea minuta Giesbrecht } \\
\text { Fritillaria borealis Lohmann }\end{array}$ & $\begin{array}{l}\text { Ectinosoma neglectum G.O. Sars' } \\
\text { Microsetella norvegica (Boeck) } \\
\text { Danielssenia typica Boeck } \\
\text { Parathemisto libellula (Lich.) } \\
\text { Harpacticus superflexus Willey* } \\
\text { Ciliates* } \\
\text { Cyclopina schneideri Scott* } \\
\text { Mertensia ovum (Fabricius) } \\
\text { Pelecypod larvae* } \\
\text { Balanus nauplii* } \\
\text { Rotifers* } \\
\text { Zaus abbreviatus G.O. Sars } \\
\text { Sarsia tubulosa (M. Sars) } \\
\text { Dactylopodia signata (Willey) }\end{array}$ \\
\hline
\end{tabular}

*Found in the Frobisher sea ice; $\left({ }^{*}\right)$ very few in the Frobisher ice

amphipod Onisimus sp. (older representatives of which were present under the ice but not taken in any of the collections on the five dates discussed here). Finally, some species collected in the plankton were not found in the ice at all. They included the copepod Metridia longa, the amphipod Parathemisto libellula, and the ctenophore Mertensia ovum, along with the copepods Calanus glacialis and $C$. hyperboreus (both absent from plankton hauls on the five dates under discussion, but common at other times in upper Frobisher Bay).

\section{DISCUSSION}

The ice cover in Frobisher Bay usually becomes stable by early December. Initially rapid growth gradually slows as the winter progresses, and maximum ice thickness occurs in late May or early June (Grainger, 1971). Breakup normally occurs a few weeks after ice growth stops. Ice covers the inner bay for close to eight months each year and clears away completely during the intervening summers. Each winter produces an entirely new ice cover; consequently no ice older than about eight months was sampled at any time. In Frobisher, therefore, the sea-ice biota is completely renewed annually, differing in that way from what is found, for instance, in the multiyear ice of the Arctic Ocean (Mel'nikov, 1980).

It is convenient to separate the animals which we associate with the sea ice into two groups. One comprises the smaller organisms (sometimes referred to as the meiofauna) which are the numerically dominant group within the ice. Most are $<1$ $\mathrm{mm}$ in maximum linear dimension, with a few up to $2-3 \mathrm{~mm}$. The second group includes larger animals found linked in various degrees to the ice, totally or partly enveloped in it, or free in the water but in close physical association with the ice. Fully grown, most of these are $>10 \mathrm{~mm}$. Young animals of the same species are of course smaller, and some of them may be included in the first group.

The large animals (mainly amphipods) were not included in the material collected for this paper. The smaller animals (Table 5) comprise a larger number of more diverse taxa than the larger animals. All clearly occur within the ice, where
TABLE 5. The meiofauna of the ice fauna of the Arctic

\begin{tabular}{|c|c|}
\hline $\begin{array}{l}\text { Protozoans } \\
\text { Ciliates } \\
\text { Helizoans* } \\
\text { Nematodes (Theristus sp.) } \\
\text { Turbellarians* } \\
\text { Polychaetes } \\
\text { Rotifers (Encentrum sp. and Proales sp. } \\
\text { Pelecypods (larvae) } \\
\text { Gastropods (larvae) } \\
\text { Cirripedes } \\
\text { Balanus sp. larvae } \\
\text { Copepods - Calanoida } \\
\text { Acartia longiremis (Lilljeborg) } \\
\text { Calanus sp. } \\
\text { Pseudocalanus sp. } \\
\text { Copepods - Cyclopoida } \\
\text { Cyclopina gracilis Claus } \\
\text { C. schneideri Scott } \\
\text { Oithona similis Claus* } \\
\text { Oncaea borealis G.O. Sars* }\end{array}$ & $\begin{array}{l}\text { Copepods - Harpacticoida } \\
\text { Dactylopodia signata (Willey)* } \\
\text { Ectinosoma finmarchicum (Scott) } \\
\text { Ectinosoma neglectum G.O. Sars } \\
\text { Hapacticus superflexus Willey } \\
\text { H. uniremis Kroyer } \\
\text { Pseudobradya sp.* } \\
\text { Tisbe furcata (Baird) } \\
\text { Copepods - Monstrilloida } \\
\text { Monstrilla sp. } \\
\text { Copepod eggs } \\
\text { Amphipods } \\
\text { Onisimus glacialis (G.O. Sars) } \\
\text { O. litoralis (Kroyer) } \\
\text { Acarina } \\
\text { Tunicates - larvae }\end{array}$ \\
\hline
\end{tabular}

*Not taken in the ice in Frobisher Bay; recorded elsewhere in the ice by Horner and Alexander (1972), Cross (1982a), Carey and Montagna (1982), Kern and Carey (1983).

some appear to undergo a major part of their life cycle. All are known to be planktonic during at least part of their lives, and are found in the plankton of ice-free as well as ice-covered water. Although they are at least temporarily pelagic, it is perhaps significant that most are included in taxa normally characterized by a bottom-living habit. Members of the group may be classed generally as feeders on small plants, bacteria and detrital particles.

Different species evidently spend different periods of their life cycles in the ice. The harpacticoid and cyclopoid copepods appear to be especially well adapted to existence within the ice, where some were found throughout their development cycles. These include Cyclopina, Tisbe, and Harpacticus, found in the ice in all stages, including adults of both sexes. Some females of Cyclopina and Tisbe were carrying eggs. In contrast, many of the larvae of benthic species, such as molluscs and barnacles, were present in the ice only during a small part of the animals' life cycles.

Most protozoans, adult worms, rotifers, adult molluscs and barnacles, harpacticoid copepods, gammaridean amphipods, mites, and adult tunicates are benthic rather than planktonic animals. These are the major animal groups inhabiting the sea ice. They are represented in the ice, however, not by holobenthic species but either by meroplanktonic young of primarily benthic adults or by holoplanktonic representatives of generally benthic groups. It is perhaps significant that the sea ice fauna is totally distinct from the dominant arctic zooplankton group, including the calanoid copepods Pseudocalanus, Calanus, and Metridia, the amphipod Parathemisto, the chaetognath Sagitta, the holoplanktonic medusa Aglantha, the ctenphore Mertensia, and the larvacean Oikopleura. These are circumpolar species found virtually everywhere in true arctic waters, but either very rare or unknown in the ice.

Herbivorous feeding by the small animal inhabitants of the ice has been mentioned in the literature (Nansen, 1906; 
TABLE 6. Representative food and predators of some of the species found in the arctic sea ice

\begin{tabular}{|c|c|c|c|}
\hline Species & Food & Predators & References \\
\hline Ciliates & $\begin{array}{l}\text { bacteria, } \\
\text { detritus, } \\
\text { diatoms, } \\
\text { dinoflagellates }\end{array}$ & $\begin{array}{l}\text { various } \\
\text { zooplankton, } \\
\text { including } \\
\text { copepods }\end{array}$ & $\begin{array}{l}\text { Beers \& Stewart } \\
\text { (1967), } \\
\text { Burkovsky (1976), } \\
\text { Beklemishev (1954) }\end{array}$ \\
\hline Heliozoans & $\begin{array}{l}\text { bacteria, } \\
\text { diatoms, } \\
\text { protozoans, } \\
\text { rotifers, } \\
\text { nematodes }\end{array}$ & & Barnes (1968) \\
\hline Nematodes & $\begin{array}{l}\text { bacteria, } \\
\text { diatoms, } \\
\text { dinoflagellates, } \\
\text { detritus, } \\
\text { small metazoans }\end{array}$ & $\begin{array}{l}\text { larger } \\
\text { nematodes }\end{array}$ & $\begin{array}{l}\text { Boaden (1964), } \\
\text { Clasby et al. } \\
\text { (1976), } \\
\text { Mclntyre (1969) }\end{array}$ \\
\hline Turbellarians & $\begin{array}{l}\text { rotifers, } \\
\text { nematodes, } \\
\text { annelids, } \\
\text { cladocerans, } \\
\text { copepods }\end{array}$ & $\begin{array}{l}\text { larger } \\
\text { turbellarians }\end{array}$ & Hyman (1951) \\
\hline Polychaete larvae & diatoms & $\begin{array}{l}\text { medusae, } \\
\text { copepods }\end{array}$ & $\begin{array}{l}\text { Barry }(1974) \text {, } \\
\text { Fraser }(1970) \text {, } \\
\text { Lebour }(1922 \text {, } \\
1923)\end{array}$ \\
\hline Mollusc larvae & diatoms & $\begin{array}{l}\text { ctenophores, } \\
\text { medusae }\end{array}$ & $\begin{array}{l}\text { Barry (1974), } \\
\text { Fraser }(1970) \text {, } \\
\text { Lebour (1922) }\end{array}$ \\
\hline Rotifers & $\begin{array}{l}\text { bacteria, } \\
\text { protozoans, } \\
\text { plant cells, } \\
\text { detritus }\end{array}$ & $\begin{array}{l}\text { larger } \\
\text { rotifers }\end{array}$ & $\begin{array}{l}\text { Barnes (1968), } \\
\text { Boaden (1964) }\end{array}$ \\
\hline Cirripede larvae & plant cells & $\begin{array}{l}\text { medusae, } \\
\text { ctenophores, } \\
\text { copepods, } \\
\text { amphipods, } \\
\text { chaetognaths, } \\
\text { fishes }\end{array}$ & $\begin{array}{l}\text { Barry (1974), } \\
\text { Fraser (1970), } \\
\text { Grainger et al. } \\
\text { (1980), } \\
\text { Lebour (1923), } \\
\text { Raymont (1963), } \\
\text { Thorson (1946) }\end{array}$ \\
\hline $\begin{array}{l}\text { Copepods } \\
\text { Acartia longiremis }\end{array}$ & $\begin{array}{l}\text { plant cells, } \\
\text { bacteria, small } \\
\text { crustaceans, } \\
\text { chaetognaths }\end{array}$ & $\begin{array}{l}\text { copepods, } \\
\text { ctenophores, } \\
\text { fishes }\end{array}$ & $\begin{array}{l}\text { Davis (1977), } \\
\text { Lebour (1922, } \\
\text { 1923), } \\
\text { Ponomarenko } \\
\text { (1967), Sorokin } \\
\text { et al. (1970) }\end{array}$ \\
\hline $\begin{array}{l}\text { Harpacticus } \\
\text { superflexus and } \\
H . \text { uniremis }\end{array}$ & $\begin{array}{l}\text { diatoms, } \\
\text { bacteria }\end{array}$ & fishes & $\begin{array}{l}\text { Brown and Sibert } \\
\text { (1977), Grainger } \\
\text { et al. (1980) }\end{array}$ \\
\hline Tisbe furcata & $\begin{array}{l}\text { plant cells, } \\
\text { bacteria, } \\
\text { fish larvae }\end{array}$ & fishes & $\begin{array}{l}\text { Brown and Sibert } \\
\text { (1977), Grainger } \\
\text { et al. (1980), } \\
\text { Berghe and } \\
\text { Bergmans (1981) }\end{array}$ \\
\hline nauplii & plant cells & $\begin{array}{l}\text { ctenophores, } \\
\text { medusae, } \\
\text { copepods, } \\
\text { amphipods, } \\
\text { mysids, } \\
\text { chaetognaths, } \\
\text { fishes }\end{array}$ & $\begin{array}{l}\text { Barry (1974), } \\
\text { Dunbar (1946), } \\
\text { Grainger et al. } \\
\text { (1980), Lebour } \\
\text { (1922, 1923), } \\
\text { Petipa et al. (1970) }\end{array}$ \\
\hline $\begin{array}{l}\text { Amphipods } \\
\text { Onisimus glacialis }\end{array}$ & diatoms & $\begin{array}{l}\text { fishes, } \\
\text { birds, } \\
\text { seals }\end{array}$ & $\begin{array}{l}\text { Bradstreet and } \\
\text { Cross (1982), } \\
\text { Dunbar (1941), } \\
\text { McLaren (1958) }\end{array}$ \\
\hline
\end{tabular}

Andriashev, 1968; Horner and Alexander, 1972; Whitaker, 1977). Bradstreet and Cross (1982) have provided by far the best information on the subject to date. No detailed studies have been done on most of the ice animals, however, and we have only rudimentary knowledge of the feeding habits of most of the ice dwellers.

All the most abundantly represented animal groups in the ice for which information on feeding habits is available are shown to feed on plant cells; some groups also feed on bacteria, ciliates, and other nanoplankton and microplankton (Table 6). Tunicate larvae are non-feeders, and we lack information on the feeding of the less common ice-inhabiting copepods.

Several species found in the plankton under the ice are small enough to inhabit the ice but seem to do so either only rarely or not at all. One of these is Oncaea borealis, which was not found in the Frobisher Bay ice during this study but is known from the ice elsewhere; it is a mixed feeder depending to a degree, although by no means entirely, on animal food. Oithona similis is another. Gauld (1966) suggested that Oithona feeds herbivorously only on large plant cells, and Petipa et al. (1970) reported that it preys on small animals at least during its late copepodite stages. Acartia longiremis, rare in the Frobisher ice, is a plant feeder in its young stages but a mixed feeder when older, according to Petipa et al. (1970). Pseudocalanus is also a rare occupant of the Frobisher Bay ice, but its diet would appear to be suited to ice feeding.

The role of the arctic cod (Boreogadus saida) as a trophic link between invertebrates and higher vertebrates was indicated some time ago by Andriashev (1954). The same author (Andriashev, 1968) described a food chain based in the antarctic sea ice extending from ice diatoms through ice-dwelling crustaceans to the broadhead fish (Trematomus), and suggested that in the Arctic, Boreogadus saida occupied a niche similar to Trematomus in the Antarctic.

There is evidence that the arctic cod does show some dependence on the ice biota, and that it is a link in an ice-based food chain. It feeds on ice-related copepods and amphipods (Bradstreet and Cross, 1982), and is eaten in turn by the searun arctic charr, birds, and seals (McAllister, 1975). At least some of the ice-related amphipods (Gammarus, Onisimus and Apherusa) feed on the species of algae which are found in the ice, and Gammarus, at least, appears to feed on crustaceans as well (Bradstreet and Cross, 1982). These amphipods too are the prey of birds and seals (Bradstreet and Cross, 1982). Specific feeding studies have not yet been done on the major copepods or larvae in the ice, but known food habits of the same species in other habitats, or of related species, indicate that all probably feed on plants and other small organic particles in the ice.

There can be no question that a considerable food supply exists in the lower part of the sea ice in Frobisher Bay, available to a large and diversified community of animals for at least five months of the year. This represents a concentration of prey substantially greater than anything to be found in the diminishing zooplankton stock below the ice in late winter and spring until the time of emergence of the new summer generation. 


\section{ACKNOWLEDGEMENTS}

We wish to thank Douglas Hope for his participation in the field work on the ice, and Daphne Pontbriand for her assistance in identifying the ice animals. Facilities at the-Ikaluit Research Laboratory at Frobisher Bay were made available by André Theriault, Indian and Northern Affairs Canada. Part of the field work was supported financially by Esso Resources Canada Limited and Canterra Energy Limited.

\section{REFERENCES}

ANDRIASHEV, A.P. 1954. Fishes of the northern seas of the U.S.S.R. Academy of Science of the U.S.S.R., Moscow-Leningrad. (Translation by Israel Program for Scientific Translations, 1964. 567 p.)

1968. The problem of the life community associated with the antaretic fast ice. In: Currie, R.I. (ed.). Proceedings of Symposium on Antarctic Oceanography. Cambridge: Scott Polar Research Institute. 147-157.

BARNARD, J.L. 1959. Epipelagic and under-ice amphipods of the central arctic basin. Scientific Studies at Fletcher's Ice Island, T-3 (1952-1955). Vol. 1:115-152.

BARNES, R.D. 1968. Invertebrate Zoology. 2nd ed. London: W.B. Saunders. $743 \mathrm{p}$

BARRY, B. 1974. Hydromedusae of the Canadian Eastern Arctic. M.Sc. thesis, McGill University, Montreal. 146 p.

BEERS, J.R., and STEWART, G.L. 1967. Micro-zooplankton in the euphotic zone at five locations across the California Current. Journal of the Fisheries Research Board of Canada 24:2053-2068.

BEKLEMISHEV, K.V. 1954. The feeding of some common plankton copepods in far eastern seas. Zoologichesky Zhurnal 33(6):1210-1229.

BERGHE, W.V., and BERGMANS, M. 1981. Differential food preferences in three co-occurring species of Tisbe (Copepoda, Harpacticoida). Marine Ecology Progress Series 4:213-219.

BOADEN, P.J.S. 1964. Grazing in the interstitial habitat: a review. In: Crisp, D.J. (ed.). Grazing in Terrestrial and Marine Environments. Oxford: Blackwell. 299-303.

BRADSTREET, M.S.W., and CROSS, W.E. 1982. Trophic relationships at high arctic ice edges. Arctic 35(1):1-12.

BROWN, T.J., and SIBERT, J.R. 1977. Food of some benthic harpacticoid copepods. Journal of the Fisheries Research Board of Canada 34:10281031 .

BUCHANAN, R.A., CROSS, W.E., and THOMSON, D.H. 1977. Survey of the marine environment of Bridport Inlet, Melville Island. Unpubl. Rep. by LGL Limited, Toronto, for Petro-Canada, Calgary. 265 p. [Available in Library, The Arctic Institute of North America, University of Calgary, Calgary, Alberta T2N 1N4.1

BURKOVSKY, I.V. 1976. Ecology of the White Sea Tintinnida (Ciliata). Zoologichesky Zhurnal 55:497-507. [Translation in Fisheries and Marine Service Translation Series Number 3878, 1976.]

CAREY, A.G., and MONTAGNA, P.A. 1982. Arctic sea ice faunal assemblage: first approach to description and source of the underice meiofauna. Marine Ecology Progress Series 8:1-8.

CLASBY, R.C., ALEXANDER, V., and HORNER, R. 1976. Primary productivity of sea-ice algae. In: Hood, D.W., and Burrell, D.C. (eds.). Assessment of the Arctic Marine Environment. The Institute of Marine Science, University of Alaska. Occasional Publication No. 4:289-304.

CROSS, W.E. 1982a. Under-ice biota at the Pond Inlet ice edge and in adjacent fast ice areas during spring. Arctic 35(1):13-27.

1982b. In situ studies of effects of oil and dispersed oil on primary productivity of ice algae and on under-ice amphipod communities. Baffin Island Oil Spill Project Working Report Series, Special Studies, 1981 Study Results. i-xiii + 1-61.

DAVIS, C.C. 1977. Sagitta as food for Acartia. Astarte 10:1-3

DUNBAR, M.J. 1941. On the food of seals in the Canadian eastern arctic Canadian Journal of Research D(19):150-155.

1946. On Themisto libellula in Baffin Island coastal waters. Journa of the Fisheries Research Board of Canada 6(6):419-434.
FRASER, J.H. 1970. The ecology of the ctenophore Pleurobrachia pileus in Scottish waters. Journal du Conseil 33(2):149-168.

GAULD, D.T. 1966. The swimming and feeding of planktonic copepods. In: Barnes, H. (ed.). Some Contemporary Studies in Marine Science. London: Allen and Unwin. 313-334.

GOLIKOVA, A.N., and SCARLATO, O.A. 1973. Comparative characteristics of some ecosystems of the upper regions of the shelf in tropical, temperate and arctic waters. Helgolander wissenschaftliche Meeresuntersuchungen 24:219-234.

GRAINGER, E.H. 1971. Biological oceanographic observations in Frobisher Bay. I. Physical, nutrient and primary production data, 1967-1970. Fisheries Research Board of Canada, Technical Report No. 265. 75 p.

and HSIAO, S.I.C. 1982. A study of the ice biota of Frobisher Bay, Baffin Island, 1979-1981. Canadian Manuscript Report of Fisheries and Aquatic Sciences No. $1647.128 \mathrm{p}$.

GRAINGER, E.H., MOHAMMED, A.A., and ROBINSON, K.E. 1980. Zooplankton biology. In: Arctic Biological Station. A Marine Biological Study of Brevoort Harbour and Nearby Waters of Eastern Baffin Island. Canadian MS report of Fisheries and Aquatic Sciences No. 1557:51-74; Appendix IV-1 - IV-5.

GREEN, J.M., and STEELE, D.H. 1975. Observations on marine life beneath sea ice. In: Proceedings of the Circumpolar Conference on Northern Ecology. Otawa: National Research Council of Canada. II-77 - II-86.

GRIFFITHS, W.B., and DILLINGER, R.E. 1981. Beaufort Sea barrier island-lagoon process studies: Final report, Simpson Lagoon. Part 5. Invertebrates. In: Environmental Assessment of the Alaskan Continental Shelf, Final Report of the Principal Investigators, Vol. 8, Biological Studies. Boulder, CO: BLM/NOAA, OSCEAP. 1-198.

HORNER, R. 1972. Ecological studies on arctic sea ice organisms. Institute of Marine Science, University of Alaska. Report R 72-17, 9 p. + appendix.

1977. History and recent advances in the study of ice biota. In: Dunbar, M.J. (ed.). Polar Oceans. Calgary: The Arctic Institute of North America. 269-283.

and ALEXANDER, V. 1972. Algal populations in arctic sea-ice: an investigation of heterotrophy. Limnology and Oceanography 17(3):454 458.

HYMAN, L.H. 1951. The Invertebrates: Platyhelminthes and Rhynchocoela, the Acoelomate Bilateria. Vol. 2. New York: McGraw-Hill. 550 p.

HSIAO, S.I.C. 1980. Quantitative composition, distribution, community structure and standing stock of sea ice microalgae in the Canadian Arctic. Arctic 33(4):768-793.

KERN, J.C., and CAREY, A.G., Jr. 1983. The faunal assemblage inhabiting seasonal sea ice in the nearshore Arctic Ocean with emphasis on copepods. Marine Ecology Progress Series 10:159-167.

LEBOUR, M.V. 1922. The food of plankton organisms. Journal of the Marine Biological Association of the U.K. 12:644-677.

1923. The food of plankton organisms. II. Journal of the Marine Biological Association of the U.K. 13:70-92.

LOVRITY, J.E. 1982. Oceanographic data from Frobisher Bay in the eastern Canadian arctic for the year 1981. Canadian Data Report of Fisheries and Aquatic Sciences No. 343. $45 \mathrm{p}$.

MacGINITIE, G.E. 1955. Distribution and ecology of the marine invertebrates of Point Barrow, Alaska. Smithsonian Miscellaneous Collection 128(9). $201 \mathrm{p}$.

MCALLISTER, D.E. 1975. Ecology of the marine fishes of arctic Canada. In: Proceedings of the Circumpolar Conference on Northern Ecology. Ottawa: National Research Council of Canada. II-51 - II-65.

McINTYRE, A.D. 1969. Ecology of marine meiobenthos. Biological Reviews 44:245-290.

McLAREN, I.A. 1958. The biology of the ringed seal (Phoca hispida Schreber) in the eastern Canadian Arctic. Fisheries Research Board of Canada. Bulletin $118.97 \mathrm{p}$.

MEL'NIKOV, I.A. 1980. The ecosystem of arctic pack ice. In: Vinogradov, M.E., and Mel'nikov, I.A. (eds.). Biology of the Central Arctic Basin Moscow: 61-96. [Canadian Translation Fisheries and Aquatic Sciences No. 4909.]

and KULIKOV, A.S. 1980. Cryopelagic fauna of the central arctic basin. In: Vinogradov, M.E., and Mel'nikov, I.A. (eds.). Biology of the Central Arctic Basin. Moscow: 97-111. [Canadian Translation Fisheries and Aquatic Sciences No. 4910.] 
NANSEN, F. 1906. Protozon on the ice-floes of the North Polar Sea. The Norwegian North Polar Expedition 1893-1896. Scientific Results S(6). 22 p.

PETIPA, T.S., PAVLOVA, E.V., and MIRONOV, G.N. 1970. The food web structure, utilization and transport of energy by trophic levels in the planktonic communities. In Steele, J.H. (ed.). Marine Food Chains. Edinburgh: Oliver and Boyd. 142-167.

PONOMARENKO, V.P. 1967. Feeding of the larvae and fry of the arctic cod (Boreogadus saida Lepechin) in the Barents and Kara Seas. Materialy Rybokhozyaistvennykh Issledovanii Severnogo Basseina 10:20-27.

RAYMONT, J.E.G. 1963. Plankton and Productivity in the Oceans. Oxford: Pergamon. $660 \mathrm{p}$.

SOROKIN, Y.I., PETIPA, T.S., and PAVLOVA, E.V. 1970. Quantitative estimate of marine bacterioplankton as a source of food. Oceanology 10(2):253-260.

THORSON, G. 1946. Reproduction and larval development of Danish marine bottom invertebrates, with special reference to the planktonic larvae in the sound ( $\emptyset$ resund). Meddelelser fra Kommissionen for Danmarks Fiskeriog Havundersogelser. Serie: Plankton, Bind 4, Nr. 1. 523 p.

USACHEV, P.I. 1949. The microflora of polar ice. Akademia Nauk SSSR. Institut Okeanologii, Trudy 3:216-259.

WELCH, H.E., and KALFF, J. 1975. Marine metabolism at Resolute Bay, Northwest Territories. In: Proceedings of the Circumpolar Conference on Northern Ecology. Ottawa: National Research Council of Canada. II-69 III-75.

WHITAKER, T.M. 1977. Sea ice habitats of Signy Island (South Orkneys) and their primary productivity. In: Llano, G.A. (ed.). Adaptations Within Antarctic Ecosystems. Washington, D.C.: Smithsonian Institution. 75-82. 